\title{
Identification of Red Meranti Group (Shorea spp., Dipterocarpaceae) Saplings Based on Variations in the Morphological Features of Quantitative Leaves (Identifikasi anakan Kelompok Meranti Merah (Shorea spp., Dipterocarpaceae) Bedasarkan Variasi Ciri Morfologi Daun Kuantitatif)
}

\author{
Nur Mufarhatun ${ }^{1 *}$, Iwan Hilwan ${ }^{2}$, and Henti Hendalastuti Rachmat ${ }^{3}$ \\ ${ }^{1}$ Department of Tropical Silviculture, Graduate School, IPB University, IPB Dramaga Campus, Bogor 16680 \\ (0251) 8622640 \\ ${ }^{2}$ Department of Silviculture, Faculty of Forestry, IPB University, IPB Dramaga Campus, Bogor 16680 (0251) \\ 8626806 \\ ${ }^{3}$ Forest Research and Development Center, Jl. Gunung Batu No. 5 Bogor 16610 (0251) 8334314
}

\begin{tabular}{|c|c|}
\hline Info artikel: & ABSTRACT \\
\hline $\begin{array}{l}\text { Keywords: } \\
\text { Shorea red meranti, } \\
\text { leaf morphology, leaf } \\
\text { color, species } \\
\text { determination }\end{array}$ & $\begin{array}{l}\text { Shorea is the largest genus within the family of Dipterocarpaceae, a major timber tree } \\
\text { dominating tropical forest in South East Asia. The genus of Shorea has many similarities, } \\
\text { and species identification is often tricky. Most Shorea (Dipterocarpaceae) species perform } \\
\text { as a big emergent tree; thus, species discrimination at seedlings level will benefit practical } \\
\text { use in the field scale. A study of variations of leaf morphology and color on Red Meranti } \\
\text { seedlings growing in an experimental nursery. A total of } 450 \text { individuals of } 29 \text { species of } \\
\text { the Red Meranti were measured for their leaf characters. Data analysis was performed } \\
\text { using the application R Statistics 3.6.0, RawTherapee 5.5, ImageJ 1.32, nixsensor, and }\end{array}$ \\
\hline $\begin{array}{l}\text { Article history: } \\
\text { Received: } \\
18 \text { March } 2021 \text {; } \\
\text { Revised: } \\
23 \text { April } 2021 ; \\
\text { Accepted: } \\
28 \text { June } 2021\end{array}$ & $\begin{array}{l}\text { encycolorpedia.id to obtain the leaf color of the observed species. Cluster analysis } \\
\text { (Hierarchical Cluster Analysis) and Principal Component Analysis (PCA) were executed } \\
\text { using IBM SPSS Statistics 25. The results showed that } 11 \text { of } 13 \text { observed leaf characters } \\
\text { were, all variables support the grouping and species kinship, and those can be as } \\
\text { determinants, except for AS and BS. Leaves color may be helpful in species determination } \\
\text { only if transformed into digital color. This study result supports current taxonomical } \\
\text { grouping based on flower and fruit characteristics. }\end{array}$ \\
\hline
\end{tabular}

\section{Introduction}

Shorea is one of the dominant tropical tree species that have high economic, ecological and environmental functions. The largest genus within Dipterocarpaceae can be classified into four timber groups, i.e., red, white meranti, yellow meranti, and Balau group. The red meranti is the largest group consisting of more than 70 species with wide distribution covering Malaya Peninsula, Southern Thailand, Sumatra, Kalimantan, Moluccas and the Philippines (Soerianegara \& Lemmens, 2002).
Leaves-based morphological species identification has been the most general practice carried out at the field scale as they are visible. Thus, the variations could be assessed quickly when compared with other characters (Hartvig, Czako, Kjaer, Nielsen, \& Theilade, 2015). This identification is also common within Shorea red meranti group. However, the identification is still challenging due to many morphological similarities (Yusniar \& Kustiyo, 2014). Nevertheless, this technique has also been known to have weaknesses as this marker strongly

Editor: Asep Hidayat, S.Hut., M.Agr., Ph.D

Korespondensi penulis: Nur Mufarhatun * (E-mail: nmufarhatun@gmail.com)

Kontribusi penulis: NM: Data collection, data tabulation and analysis, writing and editing manuscript; IH: supervise data collection, writing and editing manuscript and HHR: establish methodological framework, supervise data collection, writing and editing manuscript. 
influenced by the environment (Paria \& Bose, 2017).

According to Ashton (1982), the red meranti is grouped into five sections based on their different flower and fruits, namely the Brachypterae, Mutica, Ovalis, Pachycarpae and Rubella sections. In addition, Newman et al. (1996) reported that Section Brachypterae, Mutica, Ovalis, Pachycarpae and Rubella are considered as light hardwood, while the balau group (Section Shorea) and the yellow meranti (Section Richetioides) are considered as heavy hardwood.

In general, Shorea is known for its emerging tree with cylindrical buttressed bole. The diameter may reach $45-50 \mathrm{~cm}$ (Ashton, 1982) with a height up to 70-80 $m$ that make the trees occupy the top layer (stratum A) at a forest landscape. However, some species stand as the canopy layer in stratum B (Newman et al., 1996). Therefore, species identification at the field scale based on leaf morphology is highly constrained due to their height. Seedlings identification from the offspring growing near the mother trees becomes an alternative and an indirect approach to identifying the intended mother tree. Therefore, it is essential to develop an alternative identification method on seedlings to assist identification of the target parent trees.

\section{Methodology}

\subsection{Study site}

The study was conducted at the Nursery of Forest Research and Development Centre, Bogor City, Indonesia, from September to November 2019.

\subsection{Samples}

A total of 450 nursery-grown seedlings of 29 Shorea species belonging to the red meranti group were measured, consisting of 5-20 individuals for each species. Thirteen leaf characters were measured on 3 to 5 leaves collected from the upper part of each individual, summing 1500 leaves in total.

\subsection{Measurements}

Measurement of morphological data was carried out as those developed by Kremer et al. (2002) with some modifications to the method of $\mathrm{Wu}$ et al. (2007) and Ellis et al. (2009). The measured characteristics included lamina length (LL), petiole length (PL), leaf width at its broadest point (LW) Kremer et al. (2002), the length between the largest leaf point with the base of the leaf (LP) Ellis et al. (2009), and an angle formed between the primary and the secondary vein on the right or left sides at the broadest leaf point (SD) (Kremer et al., 2002; Ellis et al., 2009). The number of leaf veins, the shape of leaf tip (AS) and the leaf base (BS) were following (Ash et al., 1999). The measurement of leaf width (WL), the circumference of the leaf (CL), aspect ratio (AR), form factor (FF), and perimeter ratio of diameter (PR) was based on Wu et al. (2007), with the following formula:

$$
\begin{aligned}
& W L=\frac{1}{2} \times \pi+(L W \times L L) \\
& C L=\frac{1}{2} \times \pi+(L W+L L) \\
& A R=\frac{L L}{L W} \\
& F F=\frac{4 \pi X W L}{C L^{2}} \\
& P R=\frac{C L}{L W}
\end{aligned}
$$

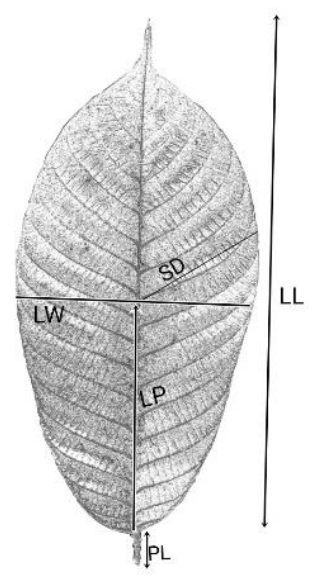

Figure 1. Measurement of leaf morphological characteristics 


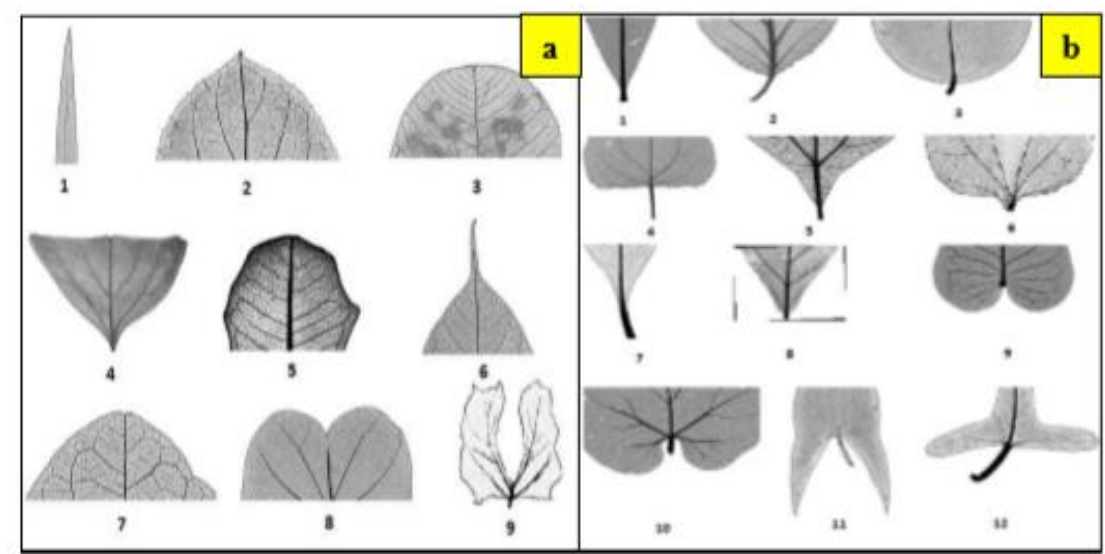

Figure 2. The shape of leaf tip (a) and the shape of leaf base (BS) (b) based on Ash et al. (1999)

Leaves' color was determined by capturing their picture and transforming them into a Munsell chart value based on a technique developed by Kendal et al. (2013). Chlorophyll content was measured using of SPAD-502 Chlorophyll Meter.

\subsection{Data analysis}

The morphological dimensions were analyzed by using comparative and multivariate analysis. The comparative test was carried out using a one-way ANOVA $F$ independent test to quantify the differences and the significance of the relationships between variables. At the same time, multivariate analysis was performed with Principal Component Analysis (PCA) to simplify the complex data by transforming it into simple dimensions. The results of transformation were displayed in the form of biplots. In addition, kinship analysis and similarities among the red meranti group species were performed using the Hierarchical Cluster Analysis method in the IBM SPSS Statistics 25. The analyzed data was a combination of morphological leaf characteristics and leaves color.

\section{Results and Discussions}

The results of morphological observations based on leave color of 29 red meranti (Shorea spp.). The color variations between species are showed in Figure 2.

This study showed that digital leaves color could be used as a standard model for identifying red meranti seedlings. All leaf colors were normally distributed following the result of the Kolmogrov-Smirnov test for distribution normal Gaussian at the 0.05 confidence level. In addition, color characterization determined that the leaves of the seedlings had a high green color and brightness with a somewhat yellowish leaf (Table 1).

The morphological differences of leaves color among these Shorea spp. might be due to differences in chlorophyll content. Chlorophyll is a green pigment found in chloroplasts at the palisade and leaf sponge parenchyma. They are very important in converting light into chemical energy that is further stored in plants. Chlorophyll content directly determines the potential photosynthesis rate and primary production (Croft \& Chen, 2017). The highest chlorophyll content among the group was showed by S. leprosula at $46.7 \mathrm{nmol} / \mathrm{cm} 2$, while the lowest was $S$. macrophylla of at 18.6 $\mathrm{nmol} / \mathrm{cm} 2$. Statistical analysis showed that the chlorophyll content differences among species were significantly different at level 0.05 . 

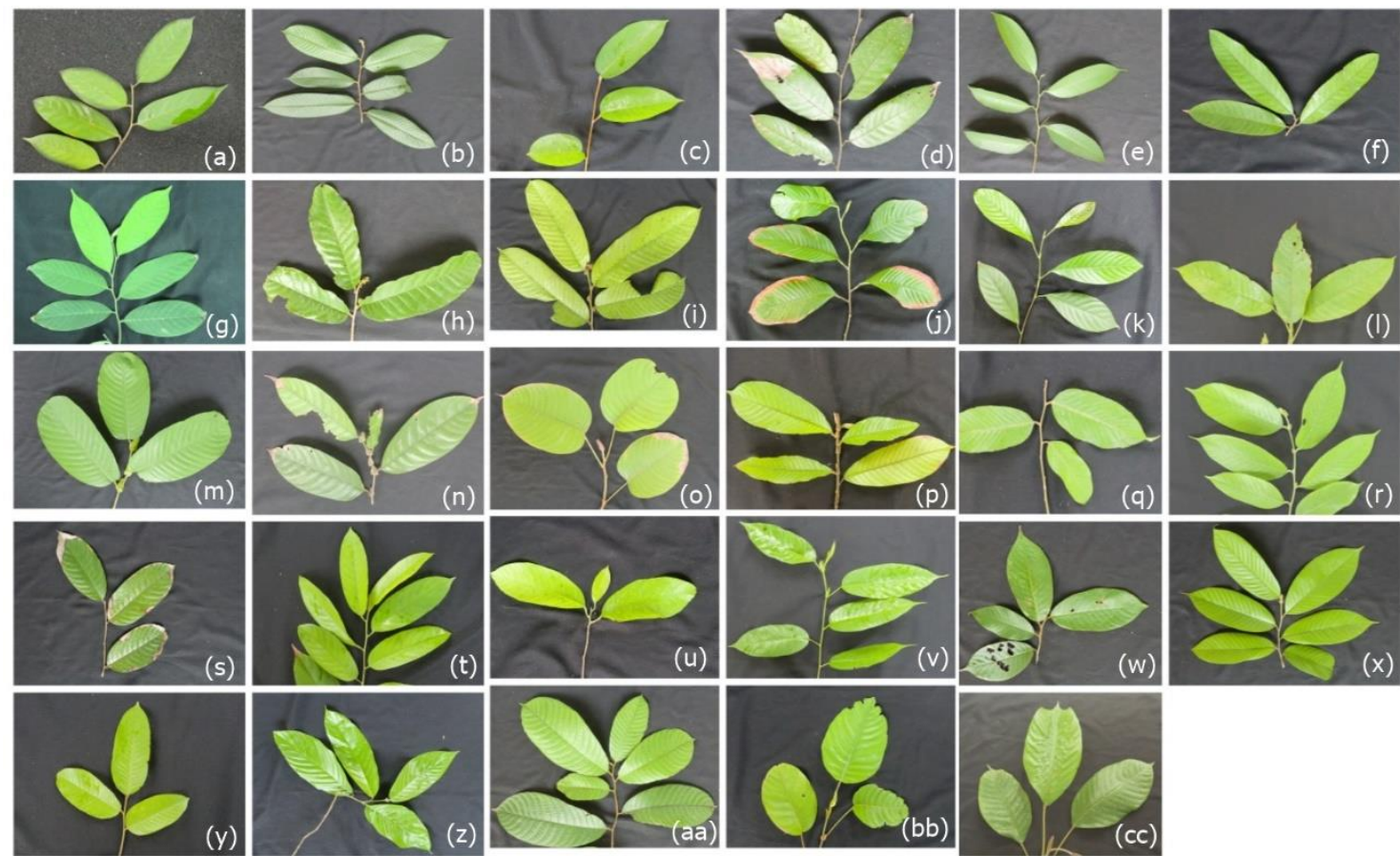

Remarks: (a) S. acuminata, (b) S. amplexicaulis, (c) S. balangeran, (d) S. beccariana, (e) S. curtisii, (f) $S$. curtisii subsp. grandis, (g) S. dasyphylla, (h) S. fallax, (i) S. hemsleyana, (j) S. johoriensis, (k) S. leprosula, (1) S. macrantha, (m) S. macrophylla, (n) S. martiniana, (o) S. mecisopteryx, (p) S. ovalis, (q) S. palembanica, (r) S. parvifolia, (s) S. parvistipulata, (t) S. pinanga, (u) S. platycarpa, (v) $S$. platyclados, (w) S. rugosa, (x) S. scaberrima, (y) S. selanica, (z) S. singkawang, (aa) S. smithiana, (bb) S. stenopthera, (cc) S. teysmaniana

Figure 3. Actual leaf color of 29 Shorea spp. of the red meranti species

Table 1. Digitally-modeled color of 29 Shorea red meranti species, and their chlorophyll content

\begin{tabular}{|c|c|c|c|c|c|c|c|}
\hline \multirow{2}{*}{ No } & \multirow{2}{*}{ Species } & \multicolumn{3}{|c|}{ RGB } & \multirow{2}{*}{$\begin{array}{c}\text { Munsell } \\
\text { Charts }\end{array}$} & \multirow{2}{*}{$\begin{array}{l}\text { Digital } \\
\text { color }\end{array}$} & \multirow{2}{*}{$\begin{array}{c}\text { Chlorophyl } \\
\text { content } \\
\text { (nmol/cm2) }\end{array}$} \\
\hline & & $\mathrm{R}$ & G & B & & & \\
\hline 1 & S. leprosula & 160 & 187 & 101 & $5 \mathrm{GY} 7 / 6$ & & 46.7 \\
\hline 2 & S. rugosa & 161 & 190 & 101 & $7.5 \mathrm{GY} 7 / 8$ & & 43.4 \\
\hline 3 & S. curtisii & 153 & 180 & 98 & 7.5GY 7/6 & & 40.5 \\
\hline 4 & S. acuminata & 163 & 202 & 102 & 7.5GY 8/10 & & 41.9 \\
\hline 5 & S. singkawang & 160 & 209 & 100 & $7.5 \mathrm{GY} 8 / 10$ & & 39.3 \\
\hline 6 & S. smithiana & 162 & 198 & 111 & $7.5 \mathrm{GY} 7 / 8$ & & 38.2 \\
\hline 7 & S. teysmaniana & 161 & 205 & 111 & $7.5 \mathrm{GY} 8 / 8$ & & 37.6 \\
\hline 8 & S. parvifolia & 154 & 199 & 110 & $7.5 \mathrm{GY} 7 / 8$ & & 39.8 \\
\hline
\end{tabular}




\begin{tabular}{|c|c|c|c|c|c|c|c|}
\hline \multirow{2}{*}{ No } & \multirow{2}{*}{ Species } & \multicolumn{3}{|c|}{ RGB } & \multirow{2}{*}{$\begin{array}{l}\text { Munsell } \\
\text { Charts }\end{array}$} & \multirow{2}{*}{$\begin{array}{l}\text { Digital } \\
\text { color }\end{array}$} & \multirow{2}{*}{$\begin{array}{c}\text { Chlorophyl } \\
\text { content } \\
\text { (nmol/cm2 }\end{array}$} \\
\hline & & $\mathrm{R}$ & G & B & & & \\
\hline 9 & S. dasyphylla & 169 & 198 & 116 & $7.5 \mathrm{GY} 7 / 6$ & & 30 \\
\hline 10 & S. johoriensis & 178 & 202 & 110 & $7.5 \mathrm{GY} 8 / 8$ & & 35 \\
\hline 11 & S. balangeran & 176 & 213 & 115 & $7.5 \mathrm{GY} 8 / 8$ & & 32.4 \\
\hline 12 & S. fallax & 176 & 215 & 109 & $7.5 \mathrm{GY} 8 / 8$ & & 35.8 \\
\hline 13 & S. scaberrima & 183 & 214 & 107 & $7.5 \mathrm{GY} 8 / 8$ & & 34.3 \\
\hline 14 & S. parvistipulata & 181 & 219 & 113 & $7.5 \mathrm{GY} 8 / 8$ & & 30.5 \\
\hline 15 & S. palembanica & 174 & 211 & 124 & $7.5 \mathrm{GY} 8 / 6$ & & 32 \\
\hline 16 & S. platyclados & 175 & 225 & 101 & $7.5 \mathrm{GY} 8 / 8$ & & 36.4 \\
\hline 18 & S. selanica & 174 & 208 & 85 & $7.5 \mathrm{GY} 8 / 10$ & & 28.8 \\
\hline 17 & S. curtisii subsp. grandis & 170 & 215 & 88 & $7.5 \mathrm{GY} 8 / 10$ & & 34 \\
\hline 19 & S. macrantha & 160 & 204 & 81 & $7.5 \mathrm{GY} 8 / 10$ & & 35.6 \\
\hline 20 & S. stenopthera & 165 & 204 & 83 & $7.5 \mathrm{GY} 8 / 10$ & & 34.5 \\
\hline 21 & S. hemsleyana & 170 & 200 & 89 & $7.5 \mathrm{GY} 8 / 10$ & & 35.5 \\
\hline 22 & S. platycarpa & 155 & 204 & 73 & $7.5 \mathrm{GY} 8 / 10$ & & 32.3 \\
\hline 23 & S. amplexicaulis & 172 & 201 & 138 & $7.5 \mathrm{GY} 8 / 6$ & & 32.6 \\
\hline 24 & S. ovalis & 189 & 212 & 87 & $5 \mathrm{GY} 8 / 8$ & & 31.8 \\
\hline 25 & S. pinanga & 191 & 231 & 95 & $5 \mathrm{GY} 8 / 8$ & & 29.3 \\
\hline 26 & S. mecisopteryx & 200 & 217 & 120 & $5 \mathrm{GY} 8 / 6$ & & 26.3 \\
\hline 27 & S. beccariana & 193 & 214 & 147 & $7.5 \mathrm{GY} 8 / 6$ & & 23.2 \\
\hline 28 & S. martiniana & 197 & 211 & 157 & $5 \mathrm{GY} 8 / 4$ & & 23.2 \\
\hline 29 & S. macrophylla & 198 & 227 & 161 & $7.5 \mathrm{GY} 9 / 4$ & & 18.6 \\
\hline
\end{tabular}


Plants with higher chlorophyll values will perform more optimum photosynthesis than lower chlorophyll content (Wang, Li, Liu, Lv, \& Wang, 2017; Yustiningsih, 2019). Chlorophyll is essential in photosynthesis by absorbing light and producing energy (Putri, Suedy, \& Darmanti, 2017). The optimal photosynthesis process will produce sugar and oxygen, which acts as food to support plant growth (Limantara, Dettling, Indrawati, Indriatmoko, \& Brotosudarmo, 2015). Sufficient food support is beneficial for vegetative organs (Hendriyani, Nurchayati, \& Setiari, 2018) and will cause relatively more leaf growth and relatively faster growth (Zhang, Huang, Bian, \& Zhao, 2013).

$S$. leprosula is a moderate growing tree with high ability to adapt to various environment condition (Mawazin \& Suhaendi, 2012; Prameswari, Supriyanto, Saharjo, Wasis, \& Pamoengkas, 2015; Erizilina, Pamoengkas, \& Darwo, 2019) and also known as light-demanding species in the early stage of growth (Abdurachman, Apriani, \& Noor, 2013; Erizilina et al., 2019). S. leprosula is widespread and generalist species (Achmad, 2017; Kit, Ng, Lee, Tnah, \& $\mathrm{Ng}, \quad 2020)$ and compare to other Dipterocarps species, it is categorized as fast growing meranti (Mashudi, Pudjiono, Rayan, \& Sulaeman, 2012; Ngatiman \&
Fajri, 2018; Tirkaamiana, Partasasmita, \& Kamarubayana, 2019) and those listed as one of priority target to be massively planted on Sistem Silvikultur Intensif (SILIN/intensive silviculture technique) with diameter growth at the range 1.15$2.20 \mathrm{~cm} /$ year across various experimental result (Mawazin \& Suhaendi, 2011; Widiyatno, Naiem, Hardiwinoto, \& Purnomo, 2011; Pamoengkas \& Prasetia, 2014; Widiyatno, Soekotjo, Naiem, Purnomo, \& Setiyanto, 2014). The high chlorophyll content may become support factors to its ability both in its adaptation capability and fast growth. Some species that showed high chlorophyll content with faster growth than others are $S$. leprosula dan $S$. platyclados. However, this particular result is not meant to propose that chlorophyll content may become the key determinant in identifying or classifying species within Shorea in the red meranti group.

In general, the quantitative leaf morphological characteristics of 29 species of red meranti (Shorea spp.) have an elongated shape. This is because the value is $A R>1$. In addition, the leaf oval and roundness rates of all observed species had almost the same value. It can be seen from the large FF and PR values. Meanwhile, the longest leaf is $S$. martiniana and the shortest is $S$. dasyphylla (Table 2).

Table 2. Quantitative leaf morphological characteristics data on 29 species of red meranti (Shorea spp.)

\begin{tabular}{lccccccccccc}
\hline Species & $\begin{array}{c}\text { LL } \\
(\mathrm{cm})\end{array}$ & $\begin{array}{c}\text { LW } \\
(\mathrm{cm})\end{array}$ & $\begin{array}{c}\text { SD } \\
\left({ }^{\circ}\right)\end{array}$ & $\begin{array}{c}\text { LP } \\
(\mathrm{cm})\end{array}$ & $\begin{array}{c}\text { PL } \\
(\mathrm{cm})\end{array}$ & LB & WL & CL & AR & FF & PR \\
\hline S. acuminata & 15.04 & 6.24 & 43.00 & 7.59 & 1.24 & 23 & 147.32 & 33.41 & 2.41 & 1.66 & 5.35 \\
S. amplexicaulis & 9.23 & 5.09 & 37.55 & 4.18 & 0.79 & 20 & 73.79 & 22.49 & 1.81 & 1.83 & 4.42 \\
S. balangeran & 10.26 & 3.18 & 26.18 & 3.18 & 1.35 & 20 & 51.16 & 21.09 & 3.23 & 1.44 & 6.64 \\
S. beccariana & 20.88 & 9.82 & 26.06 & 9.93 & 8.32 & 30 & 321.84 & 48.20 & 2.13 & 1.74 & 4.91 \\
S. curtisii & 18.39 & 6.77 & 36.44 & 7.61 & 0.86 & 31 & 195.36 & 39.49 & 2.72 & 1.57 & 5.84 \\
S. curtisii subsp. & 18.73 & 6.95 & 32.67 & 8.32 & 0.82 & 41 & 204.41 & 40.32 & 2.70 & 1.58 & 5.80 \\
grandis & & & & & & & & & & & \\
S. dasyphylla & 8.91 & 3.99 & 28.97 & 3.93 & 1.25 & 22 & 55.86 & 20.26 & 2.23 & 1.71 & 5.07 \\
S. fallax & 14.96 & 5.03 & 33.56 & 5.71 & 1.89 & 21 & 118.18 & 31.38 & 2.97 & 1.51 & 6.24 \\
S. hemsleyana & 11.30 & 4.18 & 29.67 & 4.77 & 0.88 & 20 & 74.22 & 24.31 & 2.70 & 1.58 & 5.81 \\
S. johoriensis & 11.06 & 5.85 & 38.62 & 5.93 & 1.26 & 27 & 101.64 & 26.56 & 1.89 & 1.81 & 4.54
\end{tabular}




\begin{tabular}{lccccccccccc}
\hline Species & $\begin{array}{c}\text { LL } \\
(\mathrm{cm})\end{array}$ & $\begin{array}{c}\text { LW } \\
(\mathrm{cm})\end{array}$ & $\begin{array}{c}\text { SD } \\
\left({ }^{\circ}\right)\end{array}$ & $\begin{array}{c}\text { LP } \\
(\mathrm{cm})\end{array}$ & $\begin{array}{c}\text { PL } \\
(\mathrm{cm})\end{array}$ & LB & WL & CL & AR & FF & PR \\
\hline S. leprosula & 15.35 & 6.87 & 34.17 & 7.23 & 0.87 & 24 & 165.48 & 34.88 & 2.24 & 1.71 & 5.08 \\
S. macrantha & 10.48 & 4.02 & 35.09 & 3.99 & 0.74 & 21 & 66.05 & 22.76 & 2.61 & 1.60 & 5.67 \\
S. macrophylla & 18.61 & 15.75 & 22.37 & 7.58 & 7.67 & 25 & 460.09 & 53.94 & 1.18 & 1.99 & 3.43 \\
S. martiniana & 29.01 & 13.13 & 28.67 & 14.44 & 2.30 & 39 & 597.93 & 66.16 & 2.21 & 1.72 & 5.04 \\
S. mecisopteryx & 20.42 & 17.62 & 19.56 & 7.26 & 9.62 & 31 & 550.23 & 59.00 & 1.19 & 1.99 & 3.44 \\
S. ovalis & 10.22 & 4.57 & 34.94 & 3.68 & 1.78 & 25 & 73.25 & 232.10 & 2.24 & 1.71 & 5.08 \\
S. palembanica & 11.22 & 5.51 & 36.57 & 6.65 & 2.24 & 37 & 96.97 & 26.26 & 2.04 & 1.77 & 4.77 \\
S. parvifolia & 13.77 & 5.72 & 40.00 & 5.91 & 1.08 & 23 & 123.63 & 30.59 & 2.41 & 1.66 & 5.35 \\
S. parvistipulata & 17.78 & 5.35 & 29.33 & 8.58 & 1.22 & 31 & 149.37 & 36.32 & 3.32 & 1.42 & 6.79 \\
S. pinanga & 26.88 & 13.72 & 25.67 & 14.63 & 2.50 & 32 & 578.94 & 63.74 & 1.96 & 1.79 & 4.65 \\
S. platycarpa & 12.50 & 5.05 & 37.81 & 6.88 & 1.68 & 24 & 99.17 & 27.56 & 2.47 & 1.64 & 5.45 \\
S. platyclados & 21.78 & 9.97 & 26.83 & 9.08 & 1.13 & 23 & 340.86 & 49.85 & 2.19 & 1.72 & 5.00 \\
S. rugosa & 19.07 & 7.93 & 32.17 & 7.92 & 1.15 & 26 & 237.48 & 42.39 & 2.40 & 1.66 & 5.34 \\
S. scaberrima & 14.33 & 5.40 & 37.07 & 8.82 & 1.04 & 34 & 121.46 & 30.97 & 2.65 & 1.59 & 5.74 \\
S. selanica & 19.85 & 8.87 & 25.17 & 8.67 & 0.92 & 30 & 276.33 & 45.09 & 2.24 & 1.71 & 5.09 \\
S. singkawang & 17.22 & 6.81 & 28.47 & 7.34 & 5.01 & 29 & 184.03 & 37.72 & 2.53 & 1.63 & 5.54 \\
S. smithiana & 14.14 & 8.96 & 58.72 & 5.79 & 2.18 & 23 & 198.80 & 36.26 & 1.58 & 1.90 & 4.05 \\
S. stenopthera & 20.38 & 14.62 & 19.33 & 9.31 & 1.21 & 32 & 467.57 & 54.94 & 1.39 & 1.95 & 3.76 \\
S. teysmaniana & 11.59 & 4.93 & 39.03 & 4.56 & 0.82 & 27 & 89.60 & 25.93 & 2.35 & 1.67 & 5.26 \\
\hline Rent: LW $($ Lef
\end{tabular}

Remarks: LW (Leaf width), LL (Lamina length), LP (lengthy of the widest leaf), SD (angle of leaf vein), PL (lengthy of leaf stem), LB (number of leaf vein), WL (breadth of the leaf), CL (circumference of the leaf), $\mathrm{FF}$ (form factor), AR (aspect ratio), PR (perimeter ratio of diameter)

The analysis results using PCA (Figure 4) showed that the variables of PL, BS, LW, WL, LP, LL, and LB had a positive relationship, which means that high value of one variable will be followed by high value of other variables and vice versa. On the other hand, AR and PR variables negatively correlated with $\mathrm{FF}$, while SD characteristics negatively correlated with LP.

All observed leaf morphological characteristics were statistically significant, except for the variable of tip shape (AS) and leaf base (BS). The two variables have the same value for each observed species, so that these variables cannot be used as a key determinant in species identification or grouping. Rosdayanti et al. (2020) reported that seven of 12 observed morphological characters (i.e., the circumference of leaf, area of the leaf, lamina length, leaf width, aspect ratio, form factor, and perimeter ratio of diameter) could be used as the key determinant variables for the identification of $S$. ovalis, S. leprosula, $S$. parvifolia, and $S$. guiso. Meanwhile, García, Miranda, Reyes, \& Oyama (2020) considered that the most important morphological variables were specific leaf area, leaf width, and the length of both the lamina and petiole. However, a study on Quercus dentata Thunberg and Quercus aliena Blume showed that morphological characters of petiole length and the length between the largest leaf point with the base of leaf and leaf width at its widest point have been reported to be the key determinants in identifying species or clustering the group (Liu et al., 2018). Another study on Quercus alba L., Quercus palustris Muench and Quercus velutina Lam. showed that morphological characters of leaf mass per area, petiole length, leaf area and the formed angle between the vein of the primary leaf with the secondary vein on the right or left sides at the broadest leaf point had been 
reported to be the key determinants in identifying species or clustering the group (Kusi \& Karsai, 2019). According to this study and previous study, the variable of leaf, lamina length, leaf width, and petiole length were recorded to be the major and consistent determinants in species determination both for Shorea and nonShorea.

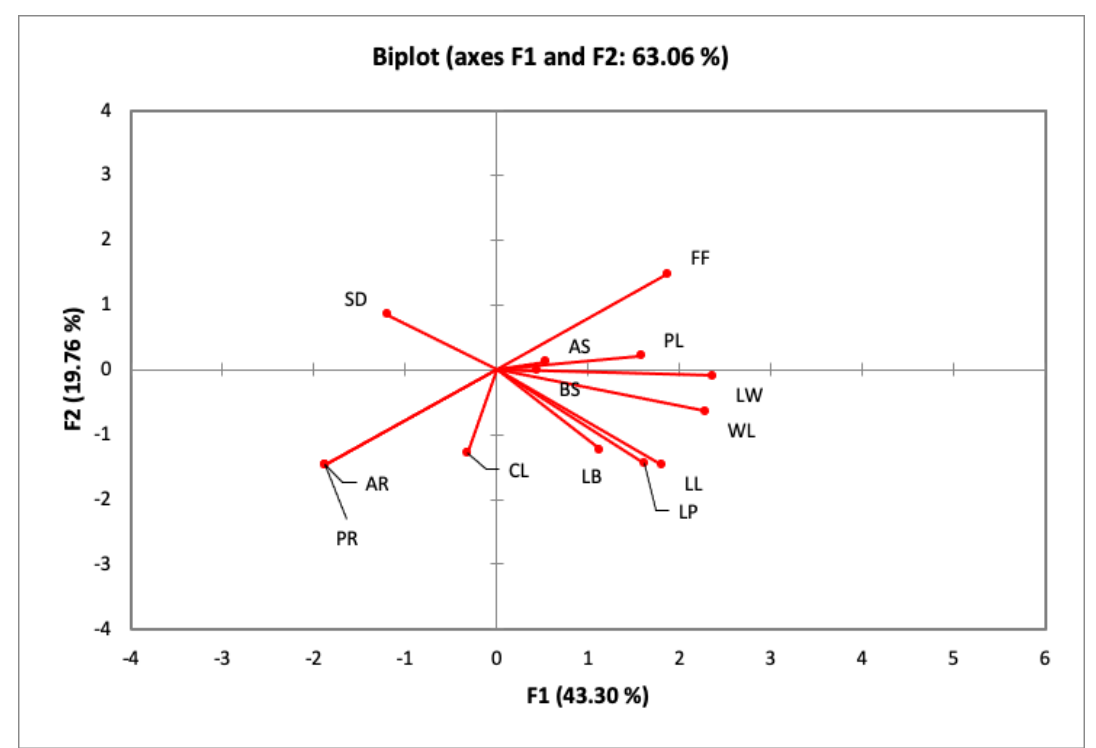

Remarks: LW (Leaf width), LL (Lamina length), LP (lengthy of the widest leaf), SD (angle of leaf vein), PL (lengthy of leaf stem), LB (number of leaf vein), AS (shape of leaf tip), BS (shape of leaf base), WL (breadth of the leaf), CL (circumference of the leaf), FF (form factor), AR (aspect ratio), PR (perimeter ratio of diameter)

Figure 4. Relationship of observed morphological leaves characteristics in 29 Shorea red meranti species

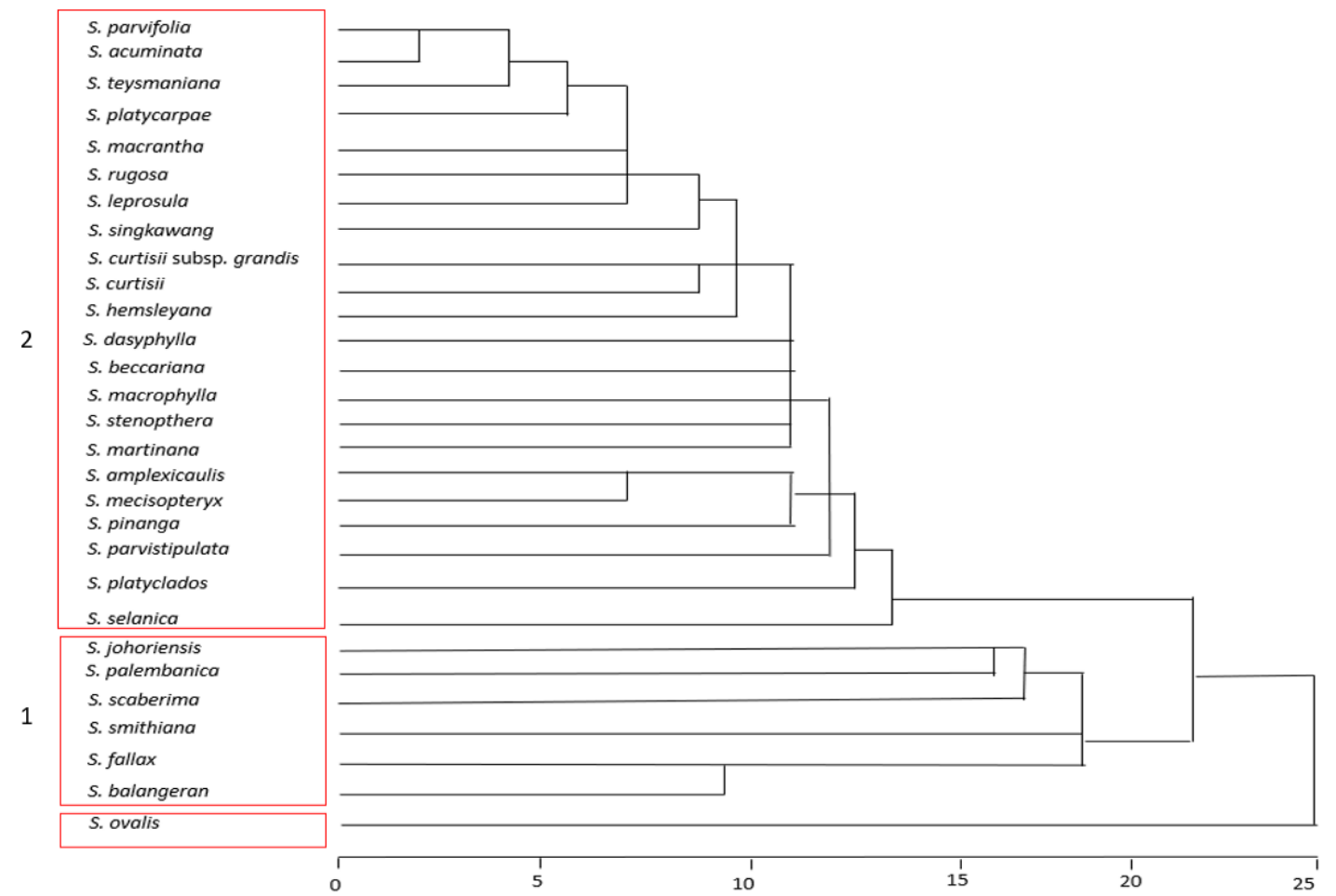

Figure 5. Leaves morphological clustering analysis of 29 Shorea red meranti species 
The result of a clustering analysis (Figure 5) determined three clusters that consisted of two main groups with $S$. ovalis separated from the two groups. Cluster 1 ( $S$. balangeran, S. fallax, S. smithiana, S. scaberrima, S. palembanica, and $S$. johoriensis) and cluster 2 ( $S$. selanica, S. platyclados, S. parvistipulata, $S$. acuminatas $S . \quad$ parvifolia, $S$. teysmaniana, S. platycarpa, S. macrantha, $S$. rugosa, S. leprosula, $S$. singkawang, $S$. curtisii, $S$. curtisii subsp. grandis, $S$. hemsleyana, $S ., \quad S$. dasyphylla, $S$. beccariana, S. macrophylla, $S$. stenopthera, $S . \quad$ martiniana, $S$. amplexicaulis, S. mecisopteryx, and $S$. pinanga).

The separation of S. ovalis from the main grouping follows the taxonomic treatment of Dipterocarpaceae (Ashton
1982). Ashton (1982) assigned S. ovalis as a monotypic species in the sections Ovalis. All types of red meranti in cluster 1 came from one section, namely Brachypterae Ashton (1982), while cluster 2 has more diverse or mixed members. Species that were included in cluster 2 came from various grouping sections, namely Mutica, Pachycarpae, and Brachypterae.

The infrageneric classification of Shorea spp. of the red meranti by Ashton (1982) was based on the flowers and fruits, while the grouping in this study was carried out based on the morphological characteristics of the leaves. However, the results of this study were fascinating as the quantitative morphological characters on the leaves of meranti saplings were in line with the grouping of Ashton (1982).

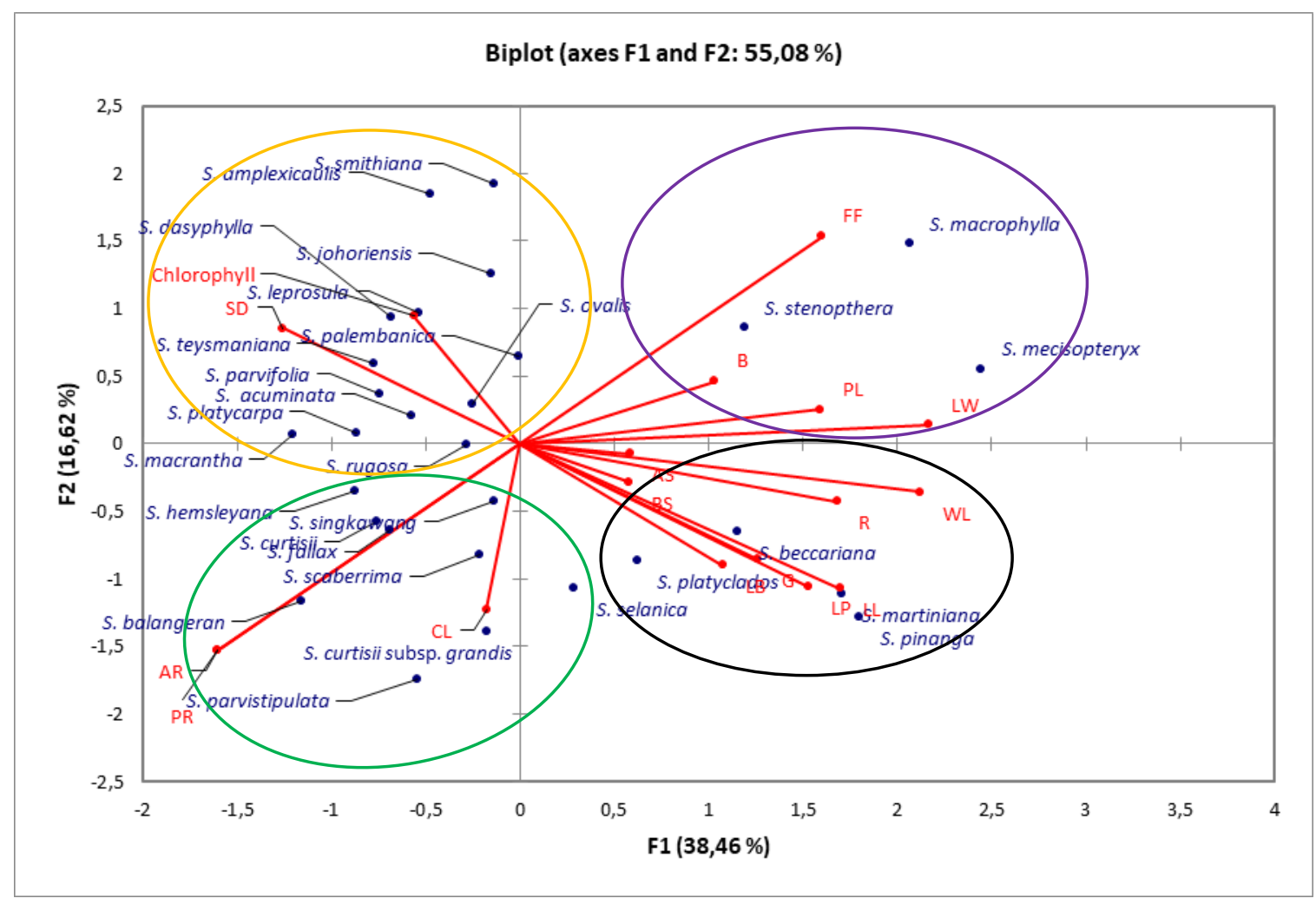

Remarks: LW (Leaf width), LL (Lamina length), LP (width of leaf width), SD (angle of leaf vein), LP (length of leaf stem), LB (number of leaf vein), AS (shape of leaf tip), BS (shape of leaf base), WL (area of the leaf), CL (circumference of the leaf), FF (form factor), AR (aspect ratio), PR (perimeter ratio of diameter), R (red), G (green), and B (blue).

Figure 6. PCA analysis of leaves morphological characters of 29 Shorea red meranti species 
Biplot analysis (Figure 6) shows that each species has different leaf morphological characteristics, both dominant and recessive. Some species such as $S$. amplexicauli, S. smithiana, S.dasyphylla, S. johoriensis, S.leprosula, $S$. palembanica, $S$. teysmaniana, S.parvifolia, S. acuminata, S. platycarpa, S. macrantha, S. regusa and S. ovalis has morphological characteristics that are more dominant in the SD variable and chlorophyll content. These types also have recessive values on the variables $\mathrm{WL}, \mathrm{R}$, G, LB, LP, and LL. It is inversely proportional to $\mathrm{S}$. beccariana, $S$. platyclados, S. smithiana, S. martiniana, and $S$. pinanga. These types have morphological characteristics that are more dominant in the variables WL, R, G, LB, LP, and LL. Furthermore, $S$. macrophylla, S. stenopthera, and $S$. mecisopteryx had more dominant characteristics in the FF, B, PL, LW variables and had the smallest values on the AR, PR, CL variables. Meanwhile, S.hemsleyana, S. singkawang, S. curtisii, S.curtisii subsp. grandis, S. scaberrima, S.fallax, S. singkawang, S. balangeran, S. parvistipulata, and $S$. selanica had morphological characters inversely proportional to $S$. macrophylla, $S$. stenopthera, and S. mecisopteryx.

This study showed that all variables determine the leaves' morphological characteristics in each type of red meranti group except for the AS and BS variables. In the biplot analysis (Figure 6), the two variables did not show a dominant value in either type of observed red meranti group. Thus, it cannot be used as a differentiator between types and in statistical analysis. The variables are also not significantly different at the 0.05 level. In comparison, leaf color can be used to determine the kinship lever only if they are transformed into digital colors in Red, Green, or Blue. The degree of closeness of the relationship variable between characters in the biplot is shown based on the angle and length of the line formed
(Figure 6). The longer the line, the more influential the character (Firmansyah, Kadiarsih, \& Taryono, 2020).

\section{Conclusions}

This study showed that all variables could characterize the morphological characteristics of the leaves in each type of red meranti group, except for the variable of tip shape (AS) and leaf base (BS). Those two variables did not support the grouping and species kinship and can be neglected as determinants. In addition, several species with similar dominant morphological characteristics were grouped into the same quadrant. While leaves color needs to be extracted digitally to use in quantifying relationship among Shorea red meranti group.

\section{Acknowledgments}

Authors thanks to Forest Research and Development Centre, the Ministry of Environment and Forestry for research permission at their conservation nursery. Our gratitude also goes to the staff of project collaboration of Forest Research and Development Centre - Komatsu for their full support in the field during sample collection, measurement and analysis.

\section{References}

Abdurachman, Apriani, H., \& Noor, M. (2013). Effect of mulching on growth performance of copper -Meranti (Shorea leprosula Miq) in Semoi, Penajam Paser Utara Regency, East Kalimantan. Jurnal Penelitian Ekosistem Dipterokarpa, 7(2), 93100.

Achmad, B. (2017). Accelerating the growth of red meranti (Shorea leprosula) wildlings by utilizing better topsoil media from under mother trees and optimum tending duration in a simple greenhouse. 
Journal of Biosciences, 10(4), 239248.

Ash, A., Ellis, B., Hickey, L., Johnson, K., Wilf, P., \& Wing, S. (1999). Manual of Leaf Architecture: Morphological Description and Categorization of Dicotyledonous and Net-veined Monocotiledonous Angiosperm. Washington (US): Smithsonian Institution.

Ashton, P. S. (1982). Flora Malesiana (I; C. G. G. J. Van Steens, ed.). Leiden (NL): Martinusgoo Nijhof Publishes.

Croft, H. \& Chen, J. B. (2017). Leaf Pigment Content. Toronto (CA): Elsevier.

Ellis, B., Douglas, C. D., Leo, J. H., Kirk, R. J., John, D. M., Peter, W., \& Scott, L. (2009). Manual of Leaf Architecture. New York (US): Cornell University.

Erizilina, E., Pamoengkas, P., \& Darwo. (2019). Correlation between physical and chemical soil properties and growth of red meranti in Haurbentes Forest Research. Jurnal Pengelolaan Sumberdaya Alam Dan Lingkungan, $9(1), \quad 68-74 . \quad$ https://doi.org/ 10.29244/jps1.9.1.

Firmansyah, Kadiarsih, S. A., \& Taryono. (2020). Penggunaan teknik analisis ammi biplot untuk mengenali aksesi wijen tahan salin. Buletin Tanaman Tembakau, Serat \& Minyak Indsutri, 12(2), 86-93. https://doi.org/ 10.21082/btsm.v12n2.2020.86-93

García, R. M., Miranda, A. T., Reyes, I. C., \& Oyama, I. (2020). Morphological differentiation among populations of quercus elliptica née (fagaceae) along an environmental gradient in Mexico and Central America. Sociedad Botanica de Mexico, 98(1), 50-65. https://doi.org/ 10.17129/botsci.2395

Hartvig, I., Czako, M., Kjaer, E. D., Nielsen, L. R., \& Theilade, I. (2015). The use of DNA barcoding in identification and conservation of Rosewood (Dalbergia spp.). Public Library of Science, 1-24.

Hendriyani, I. S., Nurchayati, Y., \& Setiari, N. (2018). Kandungan klorofil dan karotenoid Kacang Tunggak (Vigna unguiculata ( L .) Walp .) pada umur tanaman yang berbeda. Jurnal Biologi Tropika, 1(2), 38-43.

Kendal, D., Hauser, C. E., Garrard, G. E., Jellinek, S., Giljohann, K. M., \& Moore, J. L. (2013). Quantifying plant colour and colour difference as perceived by humans using digital images. Public Library of Science, 8(8), 1-11. https://doi.org/10.1371/ journal.pone.0072296

Kit, K., Ng, S., Lee, S. L., Tnah, L. H., \& $\mathrm{Ng}$, C. H. (2020). Confirmation of natural hybrid of shorea leprosula and s. curtisii in Pasir Panjang Forest Reserve, Negeri Sembilan, Malaysia. Journal of Tropical Forest Science, 32(1), 92-96. https://doi.org/ $10.26525 /$ jtfs32.1.92

Kremer, A., Dupouey, J., Deans, J. D., Cottrell, J., Csaikl, U., Finkeldey, R., ... Badeau, V. (2002). Leaf morphological differentiation between Quercus robur and Quercus petraea is stable across Western European mixed oak stands. Springer Science + Business Media, 59, 777787. https://doi.org/10.1051/forest

Kusi, J., \& Karsai, I. (2019). Plastic leaf morphology in three species of Quercus: The more exposed leaves are smaller, more lobated and denser. Wiley-Blackwell Publishing Ltd, 114. https://doi.org/10.1111/14421984.12253

Limantara, L., Dettling, M., Indrawati, R., Indriatmoko, \& Brotosudarmo, T. H. P. (2015). Analysis on the chlorophyll content of commercial green leafy vegetables. Elsevier, 14, 225-231.

Liu, Y., Li, Y., Song, J., Zhang, R., Yan, 
Y., Wang, Y., \& Du, F. K. (2018). Geometric morphometric analyses of leaf shapes in two sympatric Chinese oaks : Quercus dentata Thunberg and Quercus aliena Blume ( Fagaceae ). Springer Science + Business Media, $75,90$.

Mashudi, Pudjiono, S., Rayan, \& Sulaeman, M. (2012). The effect of population sources and parent trees on the growth of Shorea lerprosula Miq. seedlings for clonal propagation material. Jurnal Penelitian Ekosistem Dipterokarpa, 6(2), $97-$ 109.

Mawazin \& Suhaendi, H. (2011). Evaluation of plant growth in Silviculture System of Intensive Indonesian Selective Cutting and Planting ( TPTII ) in Central Kalimantan. Jurnal Penelitian Hutan dan Konservasi Alam, 8(3), 253-261.

Mawazin \& Suhaendi, H. (2012). The effect of tree spacing on diameter growth of 5 year old Shorea leprosula miq. Jurnal Penelitian Hutan dan Konservasi Alam, 9(2), 189-197.

Newman, M. F., Burges, P. F., \& Whitmore, T. C. (1996). Manual of Dipterocarps for forester: Borneo island light hardwoods. Eidenburg (GB): Royal and Botanic Garden \& CIFOR.

Ngatiman \& Fajri, M. (2018). Weed control techniques to improve Shorea leprosula Miq. in Labanan Research Forest, Berau, East Kalimantan. Jurnal Penelitian Ekosistem Dipterokarpa, 4(1), 35-48.

Pamoengkas, P. \& Prasetia, R. (2014). The growth of red meranti (Shorea leprosula miq.) with selective cuttingand line planting in areas IUPHHK-Ha Pt. Sarpatim Sentral Kalimantan. Journal Silviculture Tropica, 05(3), 174-180.

Paria, N. D. \& Bose, A. (2017). Seedling morphology and its potential in taxonomic studies in Indian Flora.
Indian Botanic Journal, 96(3\&4), 233-242.

Prameswari, D., Supriyanto, Saharjo, B. H., Wasis, B., \& Pamoengkas, P. (2015). Biopore infiltration hole and cross drain technology for rehabilitationin Skidding Road. Jurnal Penelitian Hutan dan Konservasi Alam, 12(2), 177-189.

Putri, F. M., Suedy, S. W. A., \& Darmanti, S. (2017). The effect nanosilica fertilizer on numbers of stomata, chlorophyll content, and growth of black rice (Oryza sativa L . cv. Japonica). Buletin Anatomi dan Fisiologi, 2(1), 72-79.

Rosdayanti, H., Siregar, U. J., \& Siregar, I. Z. (2020). Leaf Morphology traits of Shorea spp in Ex-Situ KHDTK Haurbentes. Media Konservasi, 24(2), 207-215. https://doi.org/ 10.29244/medkon.24.2.207-215

Soerianegara, I., \& Lemmens, R. H. M. J. (2002). Plant resources of south-east asia timber trees: Major commercial timbers. Wageningen (NL): Pudoc Scientific Publisdhers 5th.

Tirkaamiana, M. T., Partasasmita, R., \& Kamarubayana, L. (2019). Short Communication: growth patterns of Shorea leprosula and Dryobalanops lanceolata in Borneo' $\mathrm{s}$ forest managed with selective cutting with line replanting system. Journal Biodiversitas, 20(4), 1160-1165. https://doi.org/10.13057/biodiv/d200 431

Wang, Y., Li, S., Liu, L., Lv, F., \& Wang, S. (2017). Conjugated polymer nanoparticles to augment photosynthesis of chloroplasts. Angewandte Chemie, 56, 5408-5311. https://doi.org/10.1002/anie.201702 376

Widiyatno, Naiem, M., Hardiwinoto, S., \& Purnomo, S. (2011). Growth of meranti (Shorea spp.) in the selective cutting and line planting with intensive silviculture (TPTJ-SILIN). 
Jurnal Penelitian Hutan dan Konservasi Alam, 8(4), 373-383.

Widiyatno, Soekotjo, M., Naiem, S., Purnomo, \& Setiyanto, P. E. (2014). Early performance of 23 dipterocarp species planted in logged-over rainforest. Journal of Tropical Forest Science, 26(2), 259-264.

Wu, S. G., Bao, F. S., Xu, E. Y., Wang, Y., Chang, Y., \& Xiang, Q. (2007). Classification using probabilistic neural network a leaf recognition algorithm for plant. Springer Science + Business Media, 59, 777-787.

Yusniar, E. \& Kustiyo, A. (2014). Identifikasi daun Shorea menggunakan KNN dengan ekstraksi fitur 2DPCA. JIKA, 5(1), 19-24.

Yustiningsih, M. (2019). Intensitas cahaya dan efisiensi fotosintesis pada tanaman naungan dan tanaman terpapar cahaya langsung. Jurnal Pendidikan Biologi, 4(2), 44-49.

Zhang, X., Huang, G., Bian, X., \& Zhao, Q. (2013). Effect of root interaction and nitrogen fertilization on the chlorophyll content, root activity, photosyntetic chraracteristics of intercropped soybean and microbial quantity in the rhizosphere. Czech Academy of Agricultural Sciences, 59(2), 80-88. 